\title{
パルスパワーによる 大気压プラズマ生成
}

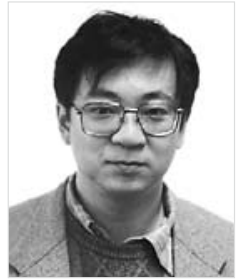

高木 浩一

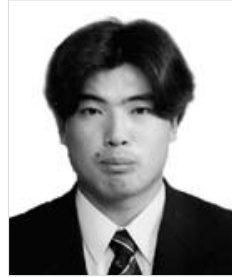

浪平 隆男

\section{1.はじめに}

大気圧プラズマで特徴的なことは，各粒子の衝突間に移 動する平均距離（平均自由行程）が短いこと，単位時間当 たりに衝突する回数 (衝突周波数) が多いことである。こ のため絶縁破壊が起こると，プラズマは電子のエネルギー が高く中性ガス温度が低い非熱平衡（低温）プラズマの状 態から，アーク放電に代表される熱平衡（熱）プラズマへ と, 短時間のうちに移行する。大気圧で非熱平衡プラズマ を生成する方法として，1）電極間に誘電体バリアを挿 入，2）高速気流や電流制限抵抗を用いる，3）短パルスを 印加電圧として利用するなどがある。本稿では，高電圧短 パルス（パルスパワー）を利用する大気圧プラズマの生成 について概説する。

\section{2. パルスパワーによる放電開始}

高電圧が電極に印加されると, 電極間に電界が生じる。 ここに存在する電子はクーロン力を受け, 運動方程式 $f=$ $m a(=e E)$ に従って加速される。この電子がガス粒子と 衝突するまでに，そのガスの電離に必要なエネルギーまで 加速された場合, 電離が起こり (衝突電離), 電子数は増 える。これらの電子は, 再び電界で加速され, 次なる電離 を引き起こす。このため, 電子数は指数関数で増加する (電子なだれ)。電子が陽極に達したときの電子数が $10^{8}$ 程

たかき・こういち（正員） 1988 年熊本大学大学院修士課程 修了。1989 年 4 月大分高専電気工学科助手。1996 年 4 月岩手 大学工学部電気電子工学科助手, 2001 年 3 月同助教授, 現在 に至る。2000 年 10 月～2001 年 9 月マクマスター大学客員研究 員。応用物理学会, 静電気学会, プラズマ・核融合学会, 放電 学会, IEEE 会員。博士 (工学)。

なみひら・たかお（正員） 1999 年熊本大学大学院工学研究 科修士課程修了。1999 年 4 月熊本大学工学部助手, 2006 年 7 月同助教授, 現在に至る。2003 年 7 月熊本大学より博士（工 学）授与。 2003 年 4 月～2004 年 3 月アメリカテキサステック 大学パルスパワー・パワーエレクトロニクスセンター客員教 授。静電気学会正員, IEEE Senior Member。
度になると, 電離により発生した空間電荷による電界が, 次の電子なだれを引き込むのに十分強くなる。このため, 電子なだれで生じた空間電荷に向かって, 次から次に後続 の電子なだれが飛び込み，プラズマは陽極から陰極に向っ て伸びるように見える。これは大気圧の放電開始時によく 見られる形態で，ストリーマ放電と称する。

ストリーマが発生する条件は，1）初期電子が存在する こと, 2) 電子が平均自由行程で電離可能な速度まで加速 されることになる。通常の $\mathrm{AC} や \mathrm{DC}$ の静的破壊では, 1）はそれほど問題にならず，2）が重要になる。このた め, 破壊電圧は $p d$ 值 (気圧×電極間距離) の関数で表さ れる (パッシェン則)。これに対して，パルスパワーは一 般には高電界短時間の現象を取り扱うため，1）や，2）で も特に放電の進展時間などの影響が大きくなる。このため 破壊電圧は，図１に示すように, $p t$ 值（気圧×パルス幅） の関数として表される。換算電界 $(E / P$; 電界を気圧で除 したもの）によりガス固有の電離レート $v_{\mathrm{i}}(1$ 秒あたりの 電離回数）が決まる。この電離レートとパルス幅を積算し たもの $\left(v_{\mathrm{i}} t\right)$ が，ストリーマ進展に必要な空間電界を作 り出せるイオン数（約 $10^{8}$ 個）を生成することが, 高電界 短パルスの破壊条件となる。

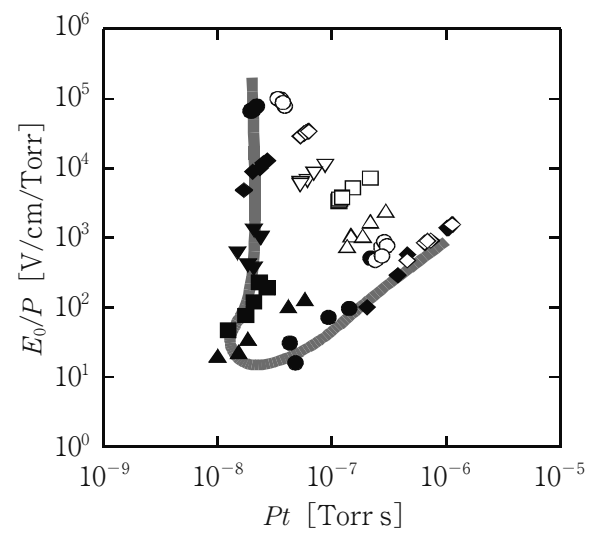

図 1 短パルスの絶縁破壊電界 ${ }^{(1)}$ (黒: 紫外線照射有, 白：照 射なし；ガス：He，ギャップ長：2 mm) 


\section{3. ストリーマ（コロナ）放電の生成と応用例}

ここでは，大気圧ストリーマ放電の生成とその応用例と して，ディーゼルエンジン排ガス中の窒素酸化物（NOx） の処理事例を概説する。

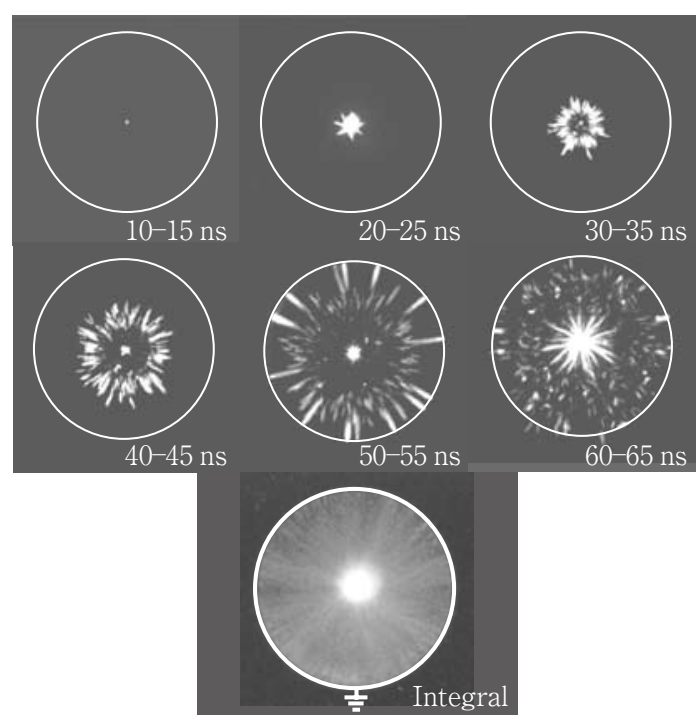

図 2 放電進展の様子 ${ }^{(2)}$ (ギャップ長 : 38 mm, 印加電圧 : 60 $\mathbf{k V}-100 \mathrm{~ns}$, 露光時間 : $5 \mathrm{ns)}$

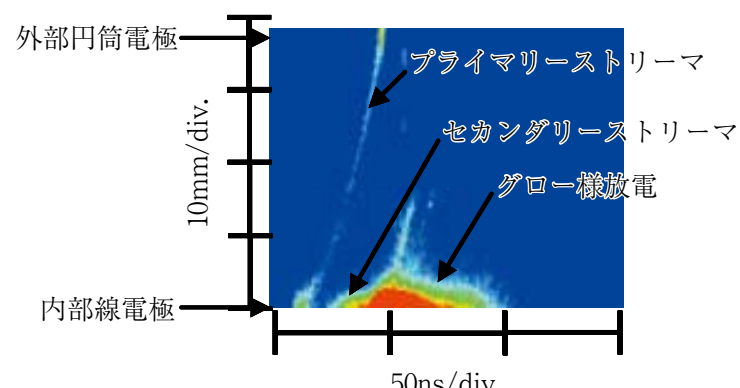

図 3 放電進展の様子 ${ }^{(3)}$ (ギャップ長 : 38 mm, 印加電圧 : 60 $\mathrm{kV}-100 \mathrm{~ns}$ )

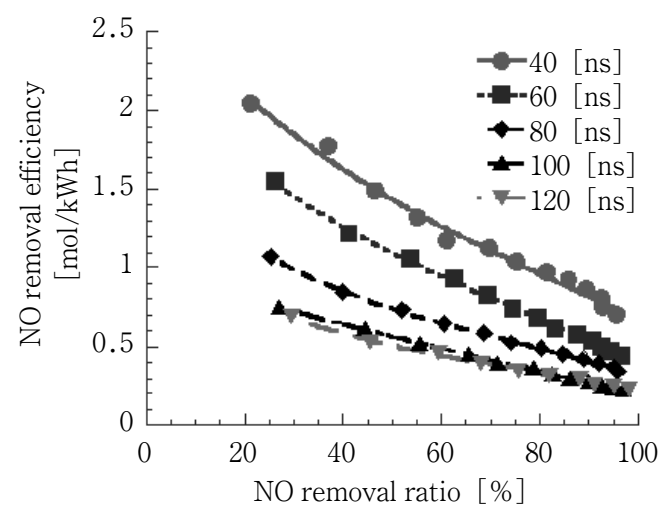

図 4 パルス幅をパラメータとした NO 除去率とエネルギー効 率の関係 ${ }^{(4)}$ (NO 初期濃度 : $200 \mathbf{p p m}$, ガス混合比 $\mathrm{N}_{2}$ : $\mathrm{O}_{2}=9: 1$, 流量 $4 \mathrm{l} / \mathrm{min}$.)
パルスパワーを用いてストリーマを発生，言い換える と，グロー放電やアーク放電へ転移させないために，パル スパワー電源に必要とされる条件として以下が挙げられ る。1）短パルス（数百 $\mathrm{ps}$ から数十 ns），2）高電圧小電 流，3）高繰り返し（kHz〜）などである。図２は同軸円 筒電極中におけるパルスストリーマ放電の高速ゲート付 ICCD カメラおよび，図３はストリークカメラによる撮影 像である。高電界領域である線電極近傍で一次ストリーマ （プライマリーストリーマ）が形成され，外部円筒電極 (接地極) へ向け進展する。一次ストリーマ形成時，線電 極表面の電界は一次ストリーマの持つ電界により緩和され るが，一次ストリーマの進展とともにその緩和状態が解消 し，再びストリーマ(二次ストリーマ：セカンダリースト リーマ）が形成・進展することとなる。なお，一次ストリ ーマの進展速度は約 $1 \mathrm{~mm} / \mathrm{ns}$ である。また，一次ストリ ーマの接地極への到達後は, 電極間インピーダンスが減 少, 放電電流が増加し, 放電はグロー様放電へと移行す る。以降，電極への電圧印加が持続すると，電流は更に急 増し，放電はアーク放電へと移行する。このため，短パル スが要求され，かつ短時間で絶縁破壊を引き起こすため, 高電圧が必要になる。なお, 放電電流は小さく, 一回の放 電でのプラズマへの注入エネルギーは小さいため，産業応 用の見地からは，パルス電圧の繰り返しを大きくし，プラ ズマに投入する平均電力を増加させる必要がある。

パルスストリーマ放電によるディーゼル模擬排ガス中の 窒素酸化物の処理例を図 4 に示す。電圧印加の短パルス化 によりNO 除去に必要なエネルギーを減少できることが分 かる。なお，この場合パルス幅 $40 \mathrm{~ns}$ はストリーマが対向 電極に到達する時間に相当する。

\section{4. 大気圧グロー放電の生成とその特性}

グロー放電の特徵は，空間的な均一性と非熱平衡性にな る。グロー放電の発生と維持のため, 印加電圧として, 空

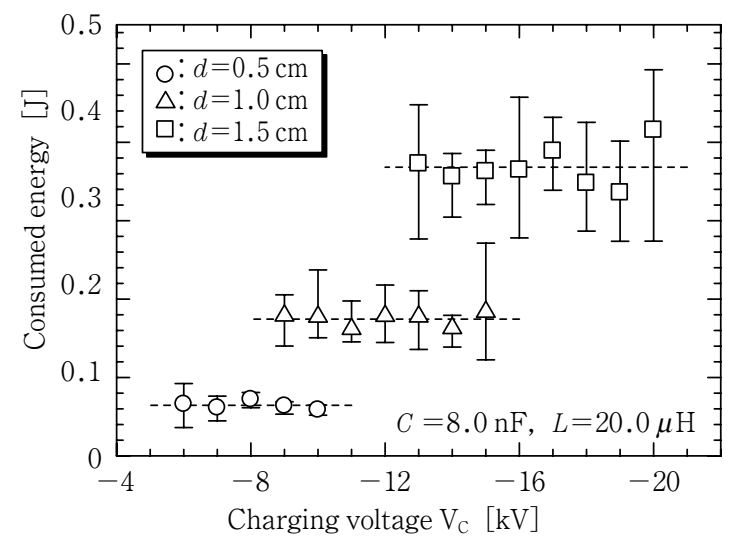

図 5 アーク転移までの放電消費エネルギー ${ }^{(5)}$ 


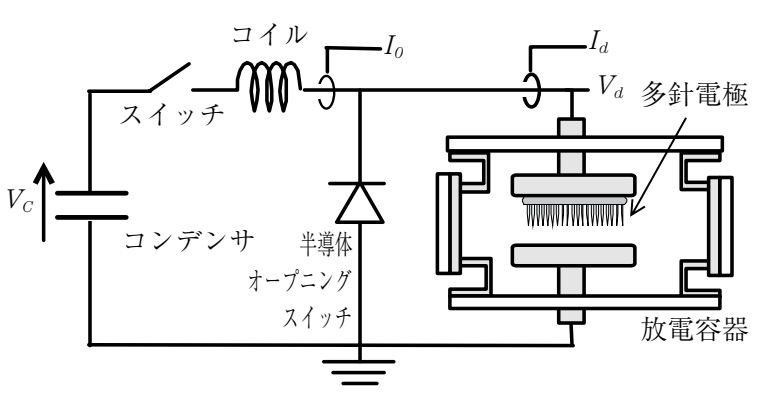

図 6 グロー放電生成用パルスパワー電源 ${ }^{(5)}$

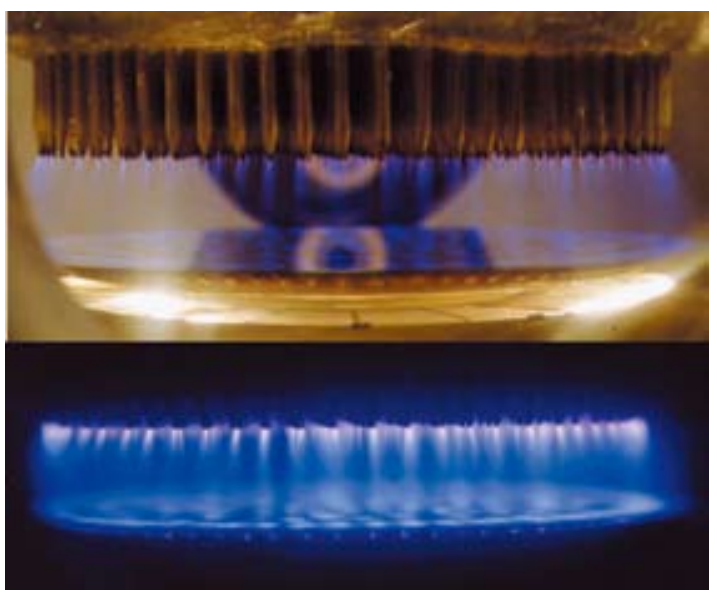

図 7 大気圧窒素グロー放電の静止写真

間的に一様に放電を発生させるための早い立ち上がり（数 百 ps〜数 ns）と，陰極近傍のシース（陰極降下領域）中 の熱的不安定性により引き起こされるアーク転移を防ぐた め，パルス幅の制御が必要になる。

一例として, 図 5 に, 大気圧窒素中でアーク転移までに 放電で消費するエネルギーを示す。エネルギーは電流・電 圧波形より，それらを積算して瞬時電力を求め，アーク転 移まで時間積分して算出している。アーク転移までに消費 するエネルギー，言い換えると，熱的不安定性が起こるエ ネルギーはおおよそ一定であり, そのエネルギー以下に電 源を設定することで，アーク転移することなくグロー放電 が得られる。エネルギーは電流と電圧の積を時間積分した ものである。グロー放電を長時間持続する場合は小電流 で，高密度プラズマの生成には大電流短パルスで駆動する ことで, 生成可能なことを示唆している。例えば短波長大 出力レーザの場合, 高密度プラズマを必要とするため, 数 $\mathrm{kA}$ の大電流，100 ns 以下の短パルスで駆動する。

パルスパワーでのグロー放電生成例として，ファース ト・リカバリー・ダイオード (FRD；図 6 では半導体才 ープニングスイッチで表記）を用いた，誘導性エネルギー 蓄積方式パルスパワー電源の回路構成例を図 6 に, 発生し た放電の様子を図 7 に示す。電極には，多数の突起を有す

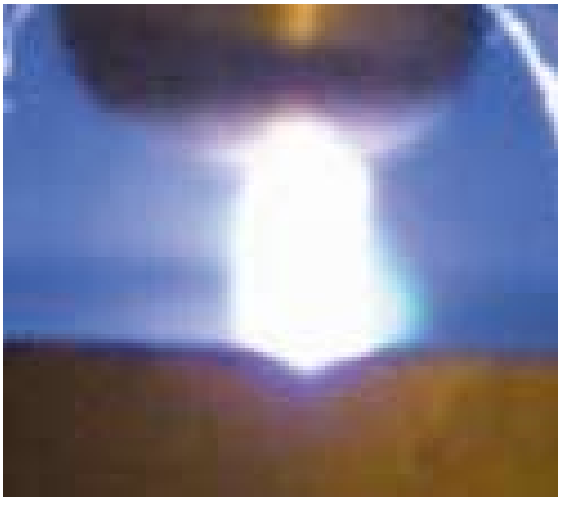

図 8 パルスアーク放電の様子（エネルギー蓄積コンデンサ： $2 \mathrm{nF}$, 充電電压 : $14.5 \mathrm{kV}$, 電極形状：棒対平板, 電極 間隔：5 mm, 電極間ガス：乾燥空気)

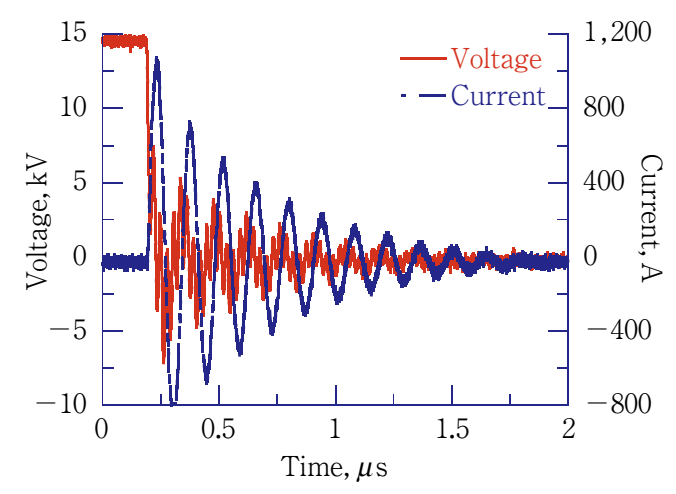

図 9 パルスアーク放電の電流・電圧波形（条件は図 8 同様）

る (剣山型) 電極を用いている。これは, 多くの場所で一 様に放電させるためである。誘導性エネルギー蓄積方式パ ルスパワー電源は，回路電流を高速で遮断するときに，イ ンダクタ両端に発生するサージ電圧を利用する。本装置の 場合，FRD が高速で電流を遮断する役割を担う。

\section{5. パルスアーク放電の生成とその応用}

アーク放電は熱平衡プラズマである。したがって，アー ク放電はパルスパワーに頼らずとも生成できる。アーク放 電にパルスパワーを用いる場合として，1）大電流高密度 プラズマの生成，2）衝撃波の生成，3）投入エネルギーの 細かい制御が必要なときになる。ここでは，パルスパワー を用いた大気圧アーク放電の生成・制御とその応用例とし て，医療用一酸化窒素（NO）の生成について概説する。

コンデンサ等の電気エネルギー蓄積媒体へ蓄積したエネ ルギーを，比較的狭い空間へ瞬時に投入すると，パルスア ーク放電が発生する。棒対平板電極間にてパルスアーク放 電を生成した例を図 8 に示す。高輝度の発光を伴うアーク プラズマ柱が形成される。このアークプラズマ柱は非常に 


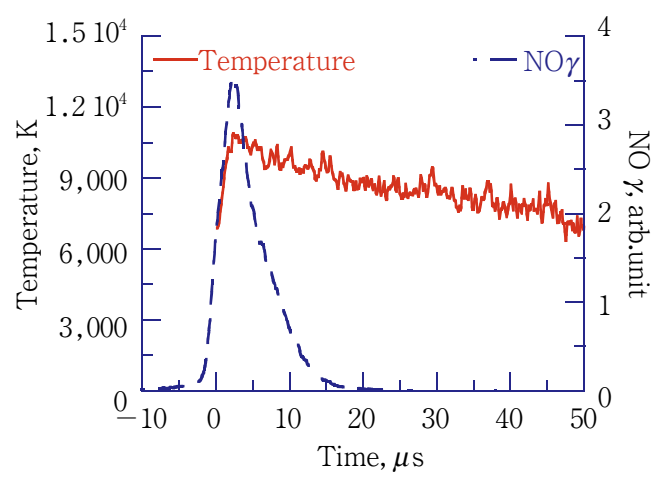

図 10 パルスアーク放電プラズマ柱の温度変化 ${ }^{(6)}$ (条件は図 8 同様）（カラーの図は口絵を参照）

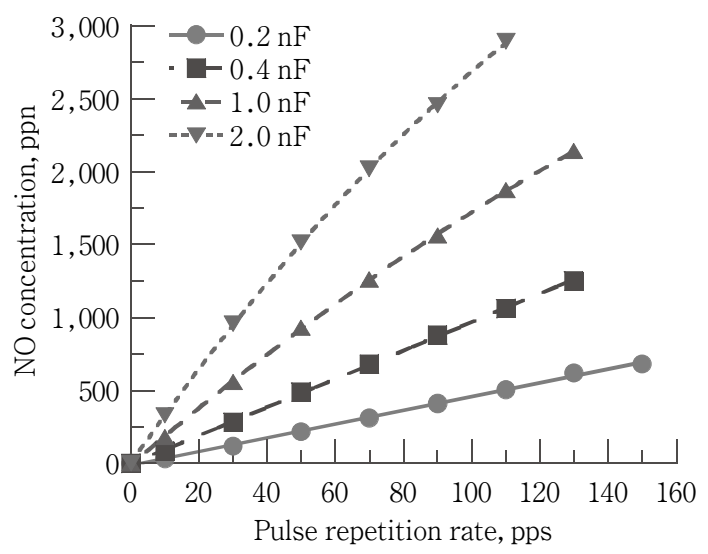

図 11 パルスアーク放電による一酸化窒素生成（乾燥空気流 量 : $300 \mathrm{~mL} / \mathrm{min}$. 他の条件は図 8 同様)

小さい抵抗值を有するため，電極間インピーダンスが急激 に低下し, 回路中ではコンデンサ等のエネルギー蓄積媒体 の充放電が繰り返される。図 9 に電圧・電流波形を示す。 アークプラズマ柱および回路中の抵抗によりエネルギーが 消費され，その波形は減衰振動となる。また，図 10 に示 されるようにアークプラズマ柱の温度は形成直後に約 $10,000 \mathrm{~K}$ へと達し, その後数十から数百 $\mu \mathrm{s}$ の時間をかけ て徐々に低下していく。この急激な温度変化を利用するこ とで温度に対し高い感度を有する化学反応を容易に制御す ることが可能となる。図 10 にアークプラズマ柱の温度と ともにNOの $\gamma$ バンドからの発光を示す。プラズマ温度の 上昇とともに発光が強くなり, プラズマ柱内での NO 生成 が裏付けられる。これは $1,000 \mathrm{~K}$ 以上の高温領域へ $\mathrm{N}_{2}$ と $\mathrm{O}_{2}$ が存在すると $\mathrm{NO}$ が生成される反応によるものである。
図 11 にはパルスアーク放電による化学反応制御の一例と して，エネルギー蓄積コンデンサ容量をパラメータとした パルスアーク放電による乾燥空気からの一酸化窒素生成特 性を示す。パルス繰り返し周波数の増加に伴って単位時間 当たりの高温持続時間の割合が増加するため，NO 濃度は 繰り返し周波数へ比例して増加し，また，エネルギー蓄積 コンデンサ容量の増加に伴い一放電当たりの高温持続時間 が増加するため，同一繰り返し周波数においてはコンデン サ容量が大きい場合に高濃度の NO を生成可能となる。

\section{6. おわりに}

パルスパワーを用いた大気圧プラズマの生成として，放 電開始，ストリーマ生成，グロー放電生成，アーク放電生 成について，またその応用例について述べた。近年，電力 用半導体デバイスの技術進展が目覚しい。パルスパワーを 用いたプラズマ生成の発展は，電力用デバイスの発展に負 う面が大きい。最後に，貴重な資料とコメントをいただい た，徳島大学の下村直行氏に，この場を借りて謝辞を述べ る。

(平成 18 年 9 月 19 日受付)

(1) N. Shimomura, D. W. Scholfield, J. M. Gahl and J. Lester: "Inves tigation of Intense Electromagnetic Transient Phenomenon and Paschen Curves for Hydrogen and Helium in Subnanosecond Regime", IEEE Transactions on Plasma Science, Vol. 28, 3, pp. 496$501(2000-6)$

(2) T. Namihira, D. Wang, S. Katsuki, R. Hackam and H. Akiyama : "Propagation velocity of pulsed streamer discharges in atmospheric air", IEEE Transactions on Plasma Science, Vol. 31, 5, pp. 1091-1094 (2003)

(3) D. Wang, M. Jikuya, S. Yoshida, T. Namihira, S. Katsuki and H. Akiyama : "Observation of pulsed streamer discharges in atmospheric air using sub-microsecond pulse generator", 15th IEEE International Pulsed Power Conference, Monterey, USA (2005)

(4) T. Namihira, S. Tsukamoto, D. Wang, S. Katsuki, R. Hackam, H. Akiyama, Y. Uchida and M. Koike: "Improvement of NOX removal efficiency using short width pulsed power", IEEE Transactions on Plasma Science, Vol. 28, 2, pp. 434-442 (2000-4)

( 5 ) K. Takaki, M. Hosokawa, T. Sasaki, S. Mukaigawa and T. Fujiwara: "Production of atmospheric-pressure glow discharge in nitrogen using needle-array electrode", Appl. Phys. Lett. 86 (15) , pp. 151501-1-3 (2005)

(6) T. Namihira, S. Sakai, K. Matsunaga, D. Wang, T. Kiyan, H. Akiyama, K. Okamoto, S. Ohira and K. Toda: "Temperature measurement of pulsed arc discharge", 16th International Conference on Gas Discharges and their Applications, Xi'an, China, Vol. 2, pp. 657-660 (2006) 